\title{
Why Communicate in Disguises: A Study on Ownership of Fake Identity Accounts in Instagram
}

\author{
$1^{\text {st* }}$ Elly Yuliawati \\ Communication Science \\ Universitas Mercu Buana \\ Jakarta, Indonesia \\ elly_yuliawati@mercubuana.ac.id
}

\author{
$2^{\text {nd }}$ Giffari Adithia Fauzan \\ Communication Science \\ Universitas Mercu Buana \\ Jakarta, Indonesia \\ 44216010094@mercubuana.ac.id
}

\begin{abstract}
The selection of Instagram as a means of communication through social media in Indonesia, currently occupies the fourth position in the world. Unfortunately, the increase of using this technology is also accompanied by many problems such as identity/profile forgery, online impersonation and other cybercrimes. Why did this happen? This research aims to find motivations for ownership of fake identity accounts on social media Instagram in Indonesia. Using the case study method with a qualitative approach, extracting data through interviews with account owners identified using false or disguised identities. The results of the study found the motivation of ownership of fake identity accounts on Instagram social media, namely: interest in using Instagram because it is easy to invite actions and reactions, inform current events, make virals, help people get real information, get financial and social benefits.
\end{abstract}

Keywords- Communication, Motivation, Identity, Fake Accounts, Instagram

\section{INTRODUCTION}

Social media is part of the lives of world citizens today, especially those who live in cities and surrounding areas. Having communities on social media is common. Although they do not know each other, they can be united with similarities to things of interest, from just hobbies to state politics, and many others.

Communication that is intertwined also varies from the communal to the intrapersonal nature, it can even build mutually beneficial relationships such as trade transactions. Through social networking sites, interpersonal relationships that are built with new individuals can develop as interpersonal relationships in the real world even though each individual has never met.

Through Instagram, users can upload all kinds of activities, complaints, concerns, appreciation, personal photos and short videos to be accessible to other users so that these activities shape the identity of the account owner. The survey shows that Instagram is a popular platform of social media in the world. America is the country that has the most Instagram users with 110 million Instagram users, the second is Brazil with 66 million users, the third is India with 64 million users. While Indonesia is in 4th place with 56 million Instagram users [1].

In line with the findings of Shama, et al (2019), a remarkable improvement in smart technology today, also followed by many problems such as profile forgery, online imitation is becoming more and more common now. Researchers have observed that $20 \%$ to $40 \%$ of profiles on online social networks like Facebook are fake profiles [2]. Crimes using Instagram have also increased, such as criminal cases, bullying and material and immaterial losses resulting from an abuse of Instagram accounts. Cable News Network $(\mathrm{CNN})$ reports that there are 95 million fake Instagram profiles [3].

Fake social media accounts in Indonesia are filled with messages containing hate speech and hoaxes with political and SARA nuances (ethnicity, religion, race and intergroupshortened as SARA). There are also fake accounts created using the name of a group, so the message uploaded will provoke the reaction of other groups to behave or act certain. Not only in political matters, but also in other fields, such as business, social, restaurants, public figures and others.

The fake accounts have a high impact on the sustainability of business models that rely on data accuracy. In addition to invading privacy, Instagram users themselves are unaware of the fake profile and its consequences [4]. False profiles also lead to several cases in Indonesia such as "Saracen" a group syndicate suspected of being a cybercriminal [5]. Dissemination of false information in social media that develops rapidly affects the community and patterns of disseminating its message [6]. Another study examines anomaly users in various categories of online social networks [7], as well as the implications or impacts of social media and social networking on students and the education world [8]. Several studies have also been carried out to identify and prevent identity fraud on social media [2] and [9], including establishing hybrid schemes to detect fake accounts on Facebook [10].

The fake account does not mean the owner is also fake, although disguised by an alias, of course there is the maker. Evidenced by the availability of direct messages for advertising, meaning that it is not really anonymous. Identifying a fake account can refer to the following characteristics: 1) Having an unreasonable number of followers, 2). There is no activity on the account suddenly, 3). Little information on accounts, 4). Spam account [11].

Shama, et al. Describe it as follows: 
TABLE I. SOURCE FROM FAKE PROFILE IDENTIFICATION IN ONLINE SOCIAL NETWORKS (SHAMA, SK.ET ALL: 2019)

\begin{tabular}{|l|l|}
\hline \multicolumn{1}{|c|}{ Attribute } & \multicolumn{1}{|c|}{ Explanation } \\
\hline Post Count & $\begin{array}{l}\text { The average number of posts created by users is expected } \\
\text { to have a low count when the account is fake. }\end{array}$ \\
\hline $\begin{array}{l}\text { Comment } \\
\text { Count }\end{array}$ & $\begin{array}{l}\text { Fake accounts share and post unwanted links and } \\
\text { advertisements which make a lower count. }\end{array}$ \\
\hline $\begin{array}{l}\text { Followers } \\
\text { Count }\end{array}$ & $\begin{array}{l}\text { Usually, fake profiles have low counts but there are high } \\
\text { follower counts then they may belong to the same group. }\end{array}$ \\
\hline Events & $\begin{array}{l}\text { They won't add or share any events, live locations } \\
\text { frequently. }\end{array}$ \\
\hline $\begin{array}{l}\text { Location } \\
\text { Post }\end{array}$ & $\begin{array}{l}\text { Fake profiles have irrelevant study and work locations. } \\
\text { users. }\end{array}$ \\
\hline Created at & $\begin{array}{l}\text { The creation date, they use the timeline for less periods of } \\
\text { time. }\end{array}$ \\
\hline Description & $\begin{array}{l}\text { They make a description to advertise and connect with } \\
\text { more numbers of people }\end{array}$ \\
\hline The & The display name and URL don't match mostly. \\
\hline
\end{tabular}

Communication is a means of transmitting messages from sender to recipient. The message is constructed (encoded) and decoded. Communication is another process or state of mind. Communication is also a tool to form an identity, both in one's own views and in others that occur when interacting socially with others.

Research on fake accounts is still focused on computer science and information technology, especially the internet and networks. It should be considered to find the reason behind the creation of this fake account. Noting the communication process that occurs in the community, and the number of accounts with fake identities on Instagram, this study aims to find the motivation of fake account ownership on Instagram social media.

\section{RESEARCH METHOD}

The case study method was chosen to get an overview of problems related to the ownership of fake accounts by collecting data from various sources. Through a qualitative approach to extracting data during interviews with eligible account holders, with the following simple criteria; (1) The owner of an Instagram account with a fake identity, (2) Based in DKI Jakarta, (3) Having a viral upload on Instagram social media, (4) Affordable and willing to be interviewed. Based on the criteria and observations of viral accounts in the community, four speakers were chosen to have fake identity accounts. Data collection through interviews, observation of account activities and their contents and other supporting documents.

The research process uses Miles and Huberman's analysis, with the following steps; (1) Data Collection, (2) Data Reduction, (3) Data Presentation, (4) Conclusion Drawing [12]. Data reduction was the selection process, the concentration of attention, simplification, abstraction, and transformation of rough data obtained in the field. Data presentation was a description of a set of arranged information that was allowed for drawing conclusions and data retrieval. Conclusion withdrawal was made since the beginning of the data collection with a continuity search of meaning of any symptoms obtained in the field, recording the linkage or pattern of explanation and its configuration [13].

\section{RESULT AND DISCUSSION}

The analysis was carried out on four informants included in the criteria of fake identity accounts, such as the user not using his real identity in the form of a user name, telephone number, account type and user biography, namely: @lambeturah_official, @ndorobeii, @mujahid212, and @kenapa_polītik.

Generally their motivation for using fake accounts is to express their opinions on the phenomenon in the community, and take advantage of the accounts they manage by selling advertising promotion services. His interest in using Instagram is because: 1) this media is popular with the public; 2) Easily invites reaction actions, and 3) Getting profits. @lambeturah_official uses Instagram to be updated on information, @ndorobeii informs current events in the community, as well as@mujahid212 and @kenapa_polltik have a goal to disseminate the latest information in the community.

Naming disguised accounts is intentional to get certain goals, such as popularity, iconic, easily known and remembered by the public. Another reason for not using the real name in creating an account is because it is an account that represents the name of the group, and is managed by several people.

Posting activity of each account is based on their own standards. @lambeturah_official, for instance, uploaded seven (7) to ten (10) different contents in a day in their instagram story, IGTV outside of the post-paid ads, while account@ndorobeii in overall features can upload 20 (twenty) content. @mujahid212 and @kenapa_Polltik do not limit the minimum daily posts, depending on the case being controversial and viral in the community.

These four accounts also have a high number of viewers on almost every information uploaded, such as @lambeturah_official 823,605 views which are accumulated after 10 hours post airing, @ndorobeii gets a response of 805 comments,@mujahid212 as many as 25,873 views 23 hours after the content was uploaded, @kenapa_polltik got 129 comments. This shows the high level of community interaction with these accounts, both pros and cons.

Every person's actions cannot be separated from the existence of motivation. Motivation is a state that is contained in a person to carry out certain activities in order to achieve a goal [14]. Motivation is the willingness to do something, while the motive is a need, desire, drive or implus [15]. Discussing motivation is always related to the factors that cause it, namely intrinsic and extrinsic factors.

Encouragement from within to disguise identity, can be caused by many things, such as the desire to freely express themselves, express their opinions, or laugh in disguise because they get responses from people who are actually known in the real world and become different when on social 
media. Blurred or false self-image makes him also not worried about the social relationships around him, even for bad expressions, even if he does not feel ashamed or worried that will affect his career, self-esteem, good name, and future because his identity has been disguised/falsified. This behavior can be confirmed in the opinion of Roger (1959) that The gap between the true self and the ideal self is called incongruity, and according to Winnicott (1960) it can lead to the creation of a "false self" that presents a more defensive and protective self that hides one's "true self." Both Winnicott and Rogers suggest that a low level of falseness is natural and may not be dangerous. However, a high level of falsehood can result in critical functions and psychological vulnerability to the offender [16], and also to others who receive false information, McKenna (2002) explains that behaving according to "someone's true self", as well as having a clear and explicit identity, tends to have positive consequences. [16] And vice versa, according to researchers someone who behaves by hiding the "true self" and choosing "false self", tends to have negative consequences. This idea is not only in offline interactions but also extends to the online environment.

Impersonation also occurs because of encouragement from the environment, groups or communities who want existence on Instagram. There are also those who want to get rewards from advertising on their Instagram accounts. Accounts that have thousands or millions followers will invite other parties to promote their products (advertisements) in the form of posts on Instagram. The rewards of this paid promotion according to sources are relatively diverse, prices start from Rp. 300,000 to millions of rupiah for one post only on an Instagram account. There are short-term benefits from fake presentations; and displaying a false self becomes rational as self-beneficial behavior. Fake accounts become fake identities, so this process is what Turkle (1995) calls "identity games", one can explore and adopt various identities that are different from one's own identity [16].

Pawito (2014) outlines two ways of interpreting ideological concepts: (a) soft meaning - ideology is better understood as a belief system that characterizes certain groups of people; and (b) meaning is strong, hard - ideology is understood as a belief system that becomes the ideals or desires of the community which then provides a reference in viewing and/or understanding reality [17]. If ideology is a set of ideas/beliefs that are systematic and directed for a specific purpose, then it can be said that the owner of this fake account has an ideology in conveying messages on Instagram social media. From interviews with the owners of these fake accounts, there emerged an ideology that was embraced or at least a concept that was believed by each account holder that according to their understanding was good to share or at least be understood.

The account of @lambeturah_official believes that spreading the latest news about artists' problems and other social cases that occur in the community is fun, because what they upload gets a variety of responses that make themselves feel recognized by the community, no matter whether the type of response is positive or negative. So the researchers argue that "fun" here is not just the news sensation, but the number of responses to the feed is large.

While the account of @ndorobeii believes that every post uploaded on Instagram's social media is merely to inform the public quickly, he also believes that by spreading information through his account it has done good. Even though it seems flat, if observed, the posts on this account actually build warmth among the citizens communicating. Although not the first to share the news because there are a number of feeds that also air on other social media, but the response of netizens is quite a lot.

The account @mujahid212 in the content uploaded by the subject matter is uploaded Islamic subjects that criticize the government, criticize the surrounding social environment, and self-criticism for adherents of Islam itself. This account positions themselves as part of the Islamic community. On the tagline it says "Not the account of the candidates' candidates, not the account of the tadpole or shucks, this is the account of Islamic defense, defending the Prophet, defending the Qur'an." The public knows that this community has supported a presidential candidate in the 2019 general election, but that image has not disappeared and there are still those who consider it a hardline Islam.

The account @kenapa_polltik, as the name suggests, takes a political theme. All types of content uploaded on Instagram are about politics in Indonesia. The content criticizes the government a lot, with material sources taken from the mainstream media such as 20 'detik.com or other mainstream media. A collection of criticisms of the government allows followers to think critically about programs that are not working properly. The feed invited public debate, both pro-government and cons. From collections of follower uploads, they are confronted with a comparison of each story. So people who follow him will find a common thread of choice of material uploaded by this account.

\section{CONCLUSION}

The research concludes that motivations of fake account holders on Instagram vary; 1). Self-encouraging factors to get pleasure, spread the news and provide the latest actual information, 2) Encouragement from the group to help people get real information, and 3) Get the benefit of the popularity (viral) activities on Instagram. Account holders get material support in various ways. Some sell paid promotion features by advertising a product and get a reward, and get operational funding from groups who have an interest.

The existence of ideological content on certain understanding is reflected in the feed on the account owner's Instagram. This shows the compatibility between ideology and its motivation using account identity fake on Instagram.

\section{REFERENCES}

[1] A. S. Wardani, "Jumlah Pengguna Instagram dan Facebook Indonesia Terbesar ke-4 di Dunia," Liputan6.com, Jakarta, 2019.

[2] S. Shama, K. S. Nandini, P. B. Anjali, and K. D. Manaswi, "Fake Profile Identification in Online Social Networks," Int. J. Recent Technol. Eng., vol. 8, no. 4, pp. 11190-11194, Nov. 2019, doi: 10.35940/ijrte.D9933.118419.

[3] I. CNN, "Facebook dan Instagram Kembali Hapus Jutaan Akun Palsu," CNN Indonesia, 2019.

[4] K. Krombholz, D. Merkl, and E. Weippl, "Fake identities in social media: A case study on the sustainability of the Facebook business model," J. Serv. Sci. Res., vol. 4, no. 2, pp. 175-212, 2012, doi: 10.1007/s12927-012-0008-z. 
[5] Z. Syahayani, "Saracen: Potret Bisnis Hoax di Indonesia," Updat. Indones., vol. XI, no. 7, 2017.

[6] A. Nugroho, "The Analysis of Hoax Spread in Social Media," J. Humanit. Soc. Sci., vol. 23, no. 6, pp. 50-60, 2018, doi: 10.9790/0837-2306065060.

[7] M. Wani Ahmad, M. Ahmad Sofi, and S. Yousuf Wani, "Why Fake Profiles: A study of Anomalous users in different categories of Online Social Networks," Int. $J$. Eng. Technol. Sci. Res., vol. 4, no. 9, pp. 320-329, 2017.

[8] W. Tariq, M. Mehboob, and M. A. Khan, "The Impact of Social Media and Social Networks on Education and Students of Pakistan," Int. J. Comput. Sci. Issues, vol. 9, no. 4, pp. 407-411, 2012.

[9] V. V. shinde Nitin Arun Khandare, Jaihind D. Mungle, Shadaf J. Warunkar, "Identification and Prevention of Fake Identities in Social Media," Int. J. Innov. Res. Technol., vol. 2, no. 11, pp. 272-277, 2016.

[10] M. Smruthi and N. Harini, "A hybrid scheme for detecting fake accounts in facebook," Int. J. Recent Technol. Eng., vol. 7, no. 5, pp. 213-217, 2019.
[11] D. Cahyadi, "Ini Ciri-Ciri Akun Palsu di Instagram yang Harus Kamu Hindari!," jalantikus.com, 2019.

[12] A. Rijali, "Analisis Data Kualitatif Ahmad Rijali UIN Antasari Banjarmasin," Alhadharah, vol. 17, no. 33, pp. 81-95, 2018

[13] F. Hamid, A. Mulyana, and M. Regina, "Motive, Meaning and Social Action of Youtube Content Creators in Indonesia," Saudi J. Humanit. Soc. Sci., no. September, 2019, doi: 10.21276/sjhss.2018.3.2.8.

[14] E. Abas, "Magnet Kepemimpinan Kepala Madrasah Terhadap Kinerja Guru." p. 37, 2017.

[15] Ubay, "Motif Adalah: Contoh, Jenis serta Perbedaan Motif dan Motivasi," Adalah.co.id, 2019. .

[16] O. Gil-Or, Y. Levi-Belz, and O. Turel, "The 'Facebookself": Characteristics and psychological predictors of false self-presentation on Facebook," Front. Psychol., vol. 6, no. FEB, 2015, doi: 10.3389/fpsyg.2015.00099.

[17] P. Pawito, "Meneliti Ideologi Media : Catatan Singkat," Profetik, vol. 7, no. 1, pp. 5-14, 2014. 